ELORE (ISSN 1456-3010), vol. $12-1 / 2005$.

Julkaisija: Suomen Kansantietouden Tutkijain Seura ry.

Toimittaneet: Outi Fingerroos ja Kaarina Koski. Taitto: Jukka Talve.

[http://cc.joensuu.fi/ loristi/1_05/pen1_05.pdf]

\title{
Kolumni:
}

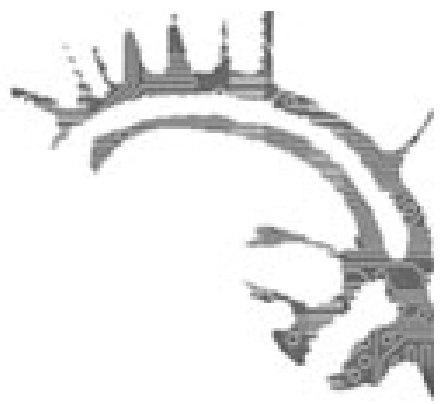

\section{Arvoituksellinen KUOLEMA}

Juha Pentikäinen

Kulttuuriantropologi Clyde Kluckhohnin mukaan kolme seikkaa näyttää erottavan ihmisen muusta eläinkunnasta: työkalujen järjestelmällinen valmistus, käsitteellinen kieli ja uskonto (ks. 1949, 57-59). Vaikka jokainen ihminen ei olekaan bomo religiosus, uskonto on yksi homo sapiensia määrittävä lajiominaisuus. Jo 30000 vuotta sitten sukupuuttoon kuolleen Neandertalin ihmisen voidaan arkeologian todistein päätellä tunteneen tulen, uhranneen ja haudanneen kuolleensa. Hänen seuraajansa Cromagnon-ihminen maalasi Euroopan kallioluoliin eläinaiheita, muotoili runsaita Venus-hahmoja ja merkitsi näkemyksensä elämän synnystä, jatkuvuudesta, kuolemasta ja kuolemanjälkeisestä elämästä kiveen. Pyhän merkit kivessä ja kalliossa ovat ihmiskunnan vanhinta kuvakieltä. Ne valaisevat hautojen ohella esihistoriallisen ihmisen suhdetta kuolemaan eri puolilla maapalloa ja Suomessakin yli 6000 vuoden takaa (ks. Pentikäinen \& Miettinen 2003).

Kluckhohnin määritelmässä kysymys on uskonnosta pienellä u-kirjaimella, sillä käsite sisältää sellaisia uskomuksia, tunteita, asenteita, menoja, tapoja ja sääntöjä, jotka ihminen tuntee tai noudattaa pitämättä niitä välttämättä uskontoon kuuluvina. Uskontoa pienellä u-kirjaimella on erityisesti kansojen luonnon- tai kansanusko, mutta se näkyy yhä ihmisten mielessä ja menoissa. Tämä viritys pätee erityisesti silloin, kun kuolema käy. Katsottakoon tästä näkökulmasta vaikkapa 2000luvun alussa tihentyneiden terrori-iskujen uutisointia mediassa. Kun iskusta on kerrottu, sen tuhot näytetty ja terroriteosta vastuun ottanut järjestö ilmoittautunut, areenalle astuvat kuolleitaan itkevät siviilit, yleensä naiset ja hautauskulkueiden lapset. Mediasotia näyttää seuraavan mediasuru, joka tekee eri puolilla maapalloa koetuista tunteista ikään kuin globaalisti yhteisiä.

\section{MoribunduS SUM - MINÄ KUOLEVAINEN}

Ihmisen kuolema on pohjimmiltaan jälkeenjääneiden ongelma; ongelmana on kuoleman odotus. Saksalainen eksistentialisti Martin Heidegger (1992, 316-317) arvosteli vuonna 1925 Marburgin yliopistossa pitämissään luennoissaan aikakauten- 


\section{Juha Pentikäinen}

sa ihmisiä olevaisuuden tyhjänpäiväistämisestä: elämä on pakoa kuoleman kasvojen edessä. Heideggerin mielestä kuolema on olemassaolon (Dasein) osa. Sen perusvarmuus kiteytyy väittämään: "Niin kauan kuin olen, olen moribundus, kuolevainen." Kuoleman ongelmallisuus ja pelko kohdistuvat nykyihmisen ajatuksissa hänen oman elämänsä päättymiseen. Traagista ei ole kuoleminen sinänsä vaan se, että Minä olen kuolevainen.

Turun linnassa vuosituhannen 1999-2000 vaihteessa järjestetyn näyttelyn Minä kuolevainen, jag är dödlig tunnuksena oli pysähtynyt kello (ks. Aboa 19951996). Näyttelyn avausluennolla ehdotin yleisölle mielen kellon pysäyttämistä hetkeksi marraskuun 14. päivään 1673. Turun tuomiokirkon alttarin katafalkilla oli silloin Upsalan ylipiston pohjalaisen osakunnan opiskelijan Martinus P. Prochaeuksen arkku, jonka eteen astui Johannes Salonius lukemaan Muistorunon. Siteeraamani runon tehtävänä oli paljastaa 330 vuotta sitten suoritettujen kuoleman menojen erilaisuus. Ruumiin maahanpano oli näytelmä ja draama, jossa papilla, omaisilla, seurakunnalla ja haudattavalla ruumiilla oli kullakin oma osansa. Kuoleman tapakulttuuri ja sitä ilmentävät käsitykset kuolemasta ja ruumiin käsittelystä ovatkin jatkuvan muutoksen alaisina, sillä vanhoista kirkonkäsikirjoista löytyy esimerkkejä sekä vanhojen tapojen tuomitsemisesta että paluusta niihin. Uudetkin rituaalit kestävät, jos ne antavat ihmisille turvaa ja kaavan kohdata suru. Kun toisen maailmansodan jälkeen alettiin sytyttää kynttilöitä sankarihaudoille, kaunis tapa levisi kaikille Suomen hautausmaille ja haudoille. Jouluaaton haudoilla käynti on ohittanut suosiossa jopa perinteisen joulukirkon.

\section{ElÄMÄ, KUOLEMA JA MUISTI}

Elämän rajojen käsittäminen määrittää sekä elämää että myös kuolemaa ja sitä, mikä ihminen on. Monissa varhaiskantaisissa yhteisöissä ihmisyksilön sosiaalinen elämä käsitettiin yhtäältä fyysistä lyhyemmäksi, toisaalta sukupolvien jatkumolla pitemmäksi. Sosiaalinen elämä alkoi yleensä nimenannosta, mutta rituaalit ovat saattaneet vahvistaa yksilön kuolettamisen jo ennen yksilön fyysisen elämän päättymistä. Nimi on yleismaailmallisesti laillistanut sukuun syntyneen lapsen oikeuden elämään ja perintöön; hän oli rintaperillinen. Lapin lapsi sai nimen mukana poromerkin ja ensimmäisen poron, oli hän sitten tyttö tai poika. Kohta hän sai myös oman joiun, luobtin. Saamelainen ilmaus "Sinä elät niin kauan kuin Sinut joiutaan" tarkoittaa melkeinpä samaa kuin suomalais-karjalainen sananparsi: "Sinä elät niin kauan kuin Sinua muistetaan.” (Pentikäinen 1998, 140; 2004, 428.)

Ihmis- ja maailmankuva määrittävät suhdetta elämään ja kuolemaan. Varhaiskristillisten skandinaavisten maakuntalakien mukaan lasta, jolla oli nimi, ei saanut jättää heitteille ja hänen surmaamisensa oli murhana käsitelty rikos. Vastaavasti inuitti-eskimo saattoi olla kunniavieras omissa hautajaisissaan, eikä hänen lähtönsä jouduttamista pidetty henkirikoksena. Myöskään pohjoisissa kulttuureissa tavanomaista vapaaehtoisen kuoleman mallia ei pidetty itsemurhana vaan elämän- 


\section{ARVOITUKSELLINEN KUOLEMA}

kohtalona (Pentikäinen 1990, 96-105). Elämän ja kuoleman välisten rajojen ongelma ei ole vieras länsimaisillekaan yhteiskunnille, sillä abortista ja eutanasiasta keskustellaan jatkuvasti.

Uskonnolla on muisti, koska sitä kannattaa pyhäksi koetun perinteen voima - myös pyhä viha - , jolla on ominaisuus paikantua ja etsiä kohteensa myös kuoleman piiristä. Suomen 1900-luvun historia osoittaa, kuinka pitkää ja ylisukupolvista vihaan ja häpeään liittyvä muisti voi olla. Kun vuoden 1918 kansalaissodan uhrien kohtalona oli poikkeava kuolettaminen, jopa ruumiin hautaamatta jättäminen tai päätyminen siunatun maan ulkopuolelle "karpalosoihin tai hiekkamonttuihin", menettely oli sama kuin vielä 1800-luvun kirkkolain säätämistä kuoleman menoista raskauttavin, häpeällinen eli "lasteellinen" hautaus.

Vaikka häpeällinen hautaus poistettiin vuoden 1868 kirkkolaista, se näyttää olleen käytössä vuonna 1918. Niinpä jälkeenjääneiden sukujen muistissa häväistyyn kuolemaan ja ruumiin kohteluun liittyneet kokemukset ovat tapahtunutta terroria ja joukkomurhia kipeämmät, kuten Suomen kansalaissodan viimeaikaiset selvitykset osoittavat (ks. Fingerroos 2004; Peltonen 1996; 2003). Kuoleman tapa- ja uskomusperinne elääkin lakeja kauemmin. Itsemurhan tehneiden ja kastamatta kuolleiden merkitsemättömät kummut Suomen hautausmaiden pohjoiskolkissa muistetaan yhä, samaten se pohjoinen portti, josta näiden kuolijoiden ruumiit hiljaisen yön hetkinä tuotiin salaa hautausmaan multiin.

\section{ASENTEET ARVOHÄMMENNYKSESSÄ}

Suomesta on toisen maailmansodan jälkeen tullut kuoleman torjuva ja kieltävä yhteiskunta. Varsinkin vuonna 1972 säädetty kansanterveyslaki näyttää kaikkien parannusten ohella laitostaneen kuoleman. Kotona synnyttäminen ja kuoleminen on sen jälkeen melkein kriminalisoitu; ennen kansanterveyslakia Suomessa oli tavallista synnyttää saunassa ja kuolla kotona. Toisaalta, vaikka kuolema onkin virallisesti laitostettu ja laillistettu kuolinsyyn määrittämistä myöten, perisuomalaisuus tunkee pinnan alta esiin ihmisten asenteissa, kokemuksissa ja tavoissa. Suomalaiset ovat edelleen kokemuksellisesti yhteyksissä vainajiin. 1980-luvulla lopulla kuoleman kanssa ammatikseen työskentelevistä ihmisistä suoritettu tutkimus osoitti, kuinka korkeastikin koulutetuilla henkilöillä oli ollut kohtaamisia kuolleiden kanssa ja vuorovaikutus rajan takaiseen on huomattavasti yleisempää kuin yleensä myönnetään (Pentikäinen 1990, 231-236; ks. myös Pentikäinen \& Achté \& Kyykkä \& Lestelä \& Hagman 1986; Ruotsalainen 1986). Kiireisen nykyihmisen ongelmana näyttääkin olevan kuoleman äärellä yksin jääminen ja se, ettei surutyölle jää tarpeeksi aikaa.

Suomalaiset ovat Euroopan maihin verrattuna uskontosuhteessaan varsin maallistuneita. Vaikka suomalaisissa on enemmän välinpitämättömiä kuin osallistuvia kirkkojen jäseniä, kirkkoihin kuulutaan yhä 85-prosenttisesti ja kirkollisten menojen asema on vahva. Kirkkohäiden suosio on nousussa, ja myös homopari- 


\section{Juha Pentikäinen}

suhteita julkistetaan rituaalein. Kuolemassa antaa yhteistä turvaa se, että uusi hautaustoimilaki velvoittaa järjestämään tilan myös kirkkoon kuulumattomille. Kuoleman menot ovat elämänkaaren rituaaleista arvostuksissa vahvoilla. Henkilökohtaista kuolemaa enemmän pelottaa jääminen ulkopuoliseksi. Suomalaiset haluavatkin liki 100-prosenttisesti tulla haudatuiksi kirkkomaahan. (Vilenius 1997, 10.)

Kolmannen vuosituhannen alun suomalainen ei kuitenkaan elä arvotyhjiössä vaan pikemminkin arvohämmennyksessä, jota leimaa tarjonnan moninaisuus ja uushaku uskonasioissa. Ihmisestä on tullut uskonnon kuluttaja valintakaupan ylipursuavan tiskin edessä, jossa etsitään vaihtoehtoja kristilliselle käsitykselle ihmisyydestä, elämästä ja kuolemasta. Pirstaletietoa muista kulttuureista ja uskonnoista tulvii median ja internet-verkostojen kautta. Uskonto privatisoituu löytäen palvonnan kohteensa jopa oman ruumiillisuuden ympäriltä. Voidaan puhua myös internet-uskonnoista, joiden yhteisönmuodostus verkkosivuilla on sekä ajan kuva että uhka.

Kuolema askarruttaa mieltä henkilökohtaisella tasolla: "Mitä ruumiilleni tapahtuu kuoleman jälkeen?” Suomen kaltainen yhä lähes yhden uskonnon kansa ei näytä olevan lainkaan yksimielinen tilasta, jossa ollaan kasvotusten kuoleman kanssa. Ajatus jälleensyntymästä tai sielunvaelluksesta kiehtoo useiden mieltä, ja valmiiden vastausten sijasta etsitään vaihtoehtoja. Kuoleman menoissa nousevat esille myös vanhat tavat, joille kirkot ovat antaneet jälleen tilaa. Ihmisoikeuksiin kuuluu oikeus kuolla omalla äidinkielellään, kulttuurinsa perinteiden mukaan. (Pentikäinen 1998, 142.)

\section{KiRJALLISUUS}

ABOA 1995-1996. Ks. Pentikäinen 1999.

FINGERROOS, OUTI 2004: Haudatut muistot. Rituaalisen kuoleman merkitykeset Kannaksen muistitiedossa. Suomalaisen Kirjallisuuden Seuran Toimituksia 985. Helsinki: Suomalaisen Kirjallisuuden Seura.

HEIDEGGER, MARTIN 1992: History of the Concept of Time. Bloomington: Prolegomena.

KLUCKHOHN, CLYDE 1949: Mirror for Man: The Relation of Anthropology of Modern Life. New York: Whittlesey House.

KOIVULEHTO, JORMA 1996: Elämän ja kuoleman sanoja. - Virittäjä 100(3): 322-339.

PELTONEN, ULLA-MAIJA 1996: Punakapinan Muistot. Tutkimus työväen muistelukerronnan muotoutumisesta vuoden 1918 jälkeen. Suomalaisen Kirjallisuuden Seuran Toimituksia 657. Helsinki: Suomalaisen Kirjallisuuden Seura.

- 2003: Muistin paikat. Vuoden 1918 sisällissodan muistamisesta ja unobtamisesta. Suomalaisen Kirjallisuuden Seuran Toimituksia 894. Helsinki: Suomalaisen Kirjallisuuden Seura. 


\section{ARVOITUKSELLINEN KUOLEMA}

PENTIKÄINEN, JUHA 1990: Suomalaisen lähtö. Kirjoituksia pohjoisesta kuolemankulttuurista. Suomalaisen Kirjallisuuden Seuran Toimituksia 530. Helsinki: Suomalaisen Kirjallisuuden Seura.

- 1994: Kuolema suomalaiseen tapaan. - Jalonen, Katariina \& Westermarck, Harri \& Lindstedt, Varpu (toim.), Ibmiselämän rajat. Studia mortis. Helsinki: Yliopistopaino.

- 1999: Suomalaiset kuolemankulttuurit murroksessa. - Willner-Rönnholm, Margareta et al. (toim.), ABOA 1995-1996. Turun makuntamuseon vuosikirja 59-60. Turku: Turun maakuntamuseo.

— 1998: Itä, länsi ja pohjoinen suomalaisten mielenmaisemassa. - Ojanen, Eero (toim.), Tubkaa ja linnunrata. Henkisyys mielenterveystyössä. Helsinki: Suomen Mielenterveysseura, SMS-julkaisut.

- 2004: Auringonpojan luobti ja Lemminkäisen luotteet. Oliko saamelaisilla epiikkaa vai ei? - Siikala, Anna-Leena \& Harvilahti, Lauri \& Timonen, Senni (toim.), Kalevala ja laulettu runo. Suomalaisen kirjallisuuden Seuran toimituksia 958. Helsinki: Suomalaisen Kirjallisuuden Seura.

PENTIKÄINEN, JUHA \& ACHTÉ, KALLE \& KYYKKÄ, TIMO \& LESTELÄ, PAULA \& HAGMAN, HARRIET 1986: Kuoleminen ja ammatti: ammatillisen ja henkilökohtaisen kuolemanläheisyyden yhteydestä kuolemanasenteisiin. - Suomen antropologi 86(4): 187-200.

PENTIKÄINEN, JUHA \& MIETTINEN, TIMO 2003: Pyhän merkit kivessä. Jyväskylä: Etnika.

RUOTSALAINEN, KARI 1986: Kuolema osana työtä. Tutkimus eräiden kaupungistuneessa ybteisössä vainajan kësittelystä ja hautajaisjärjestelystä buolebtivien ammattirybmien asennoitumisesta kuolemaan. Julkaisematon pro gradu -tutkielma. Helsinki: Helsingin yliopisto, uskontotieteen laitos.

VILENIUS, EILA 1997: Kirkolliset toimituksetpalveluna. Seurakuntalaisten palvelunlaatuodotusten toteutuminen kasteen, aviolïttoon vibkimisen ja bautaan siunaamisen ybteydessä. Kirkon tutkimuskeskus, sarja A, nro 71. Tampere : Kirkon tutkimuskeskus. 